coincidence my friend and colleagne, Mr. Muirhead Little, bas operated on an excellent example of double hammer toe with contraction of the plantar fascia.

I notice that $\mathrm{Mr}$. Anderson describes hammer toe as more sreauently affecting the little toe than any of the others. This is not in accord with the experience of most observers, and I fancy that what has been regarded as hammer toe in some of the cases ${ }^{2}$ to which Mr. Anderson alludes is a condition of curling of the little toe, which is due to lateral compression of the foot by badly fitting boots. The little, fourth, and third toes are frequently, as it were, doubled up from this cause, the degree of folding decreasing from the little toe inwards.

Harley-street, W., Aug. 19th, 1891.

F. R. Fisher.

\section{THE HYDERABAD COMMISSION AND CHLOROFORM SYNCOPE.}

To the Editors of THE LANCET.

SIRS,-Referring to an annotation in THE LANCET on a "New'Taeory of Chloroform Syncope," recently published by ne, Surgeon-Major Lawrie says, in your issue of the 8 th inst. that the exact value of this theory may be measured by two facts ; one being that the Hyderabad Commission has proved that there is no such condition as chloroform syncope, and the other that the new theory is based on views which Syme never held. It is true that the explanation I have offered as to the causation of primary syncope was never suggested by Simpson or Syme, however much their doctrine of the necessity of giving plenty of the anæsthetic may lend countenance to it. But, according to Surgeon-Major Lawrie, I have misrepresented them in saying that they taught this necessity. It appears to me that his own quotation from Syme justifies every thing I have said. "Secondly," as he himself quotes, "if this is attended to, the more rapidly the chloroform is given the better, till the effect is produced; and hence we do not stint the quantity of the chloroform." I take this to mean we give " plenty of it," and could quote the language of numerous correspondents showing that they so understand it, although it is evident that for the Hyderabad Commission the words have no meaning at all. I can quote from memory, almost verbatim, Simpson's description of his own practice, and I think this will gatisfy the readers of THE IAANCET. "The quantity which I first pour on the towel," said he, "is usually three or four drachms" (the italics, I believe, are in the original), "and I renew this in a minute or so, if necessary." To those who setk safety in drop doses of the dangerous agent half an ounce every minute must surely seem a sufficiently strong and overwhelming dose of the poison. I hold this doctrine to be the whole secret of successful administration, and to those who do not believe that it formed any part of the teaching of Syme and Simpson I can only answer, that if it was not theirs, it is mine, and I am prepared to stand by it. Surgeon-Major cawrie assumes that in fatal cases the administrator goes beyond the stage of anæsthesia and stertorous breathing, while I believe that in such cases be stops $f \star r$ short of this stage, that he practically gives no chloroform at all, and that reaction and syncope are the consequence. The Commission directs the chloroformist, if the breathing becomes irregular, to stop and begin again. On the contrary, I warn lim that he is to be prepared for considerable irregularities in this function, and may even encounter a pause of a whole minute during which the patient takes not a single inspiration, and in spite of which he is to go on with the chloroform. Even if space permitted, it would hardly be worth while to go into detail as to the proof that there is such a condition as chloroform syncope. But I may say a few words about apnoea, or the pause which may occur in the respiration in the early stages, as it is a subject which the Commission has passed orer in total silence, and as I believe it to have a direct practical bearing on some recent and lamentable fatal cases. We are told in these cases that in two minutes the breathing ceased, that the administrator at once stopped the chloroform, but that, nevertheless, fatal syncope resulted. The advice of the Commission having been carefully attended to, we may ask-Why the fatal issue? My answer is, that it was the natural consequence of the recommendation of the Commission being followed. The chloroformist mistook what was only a temporary panse in the breathing for respiratory paralysis, due to an

2 The LANCET, Aug. 1st, 1891, p. 214. overdose of the poison, promptly stopped the administration, and the syncope was the result of this stoppage. Had he gone on with the administration all would have been well, and there would have been no syncope. If I hold the teaching of the Commission responsible for the recent increase in the mortality from chloroform, I have some justification for doing so, for I have independent testimony that I predicted this would be the result. If the authority of the Commission were to remain, the death.knell of chloroform as an anrsthetic has been sounded. I am, Sirs, yours obediently, Crieff, Perthshire, Aug. 15th, 1891. ROBERT KIRK, M.D.

\section{DEATH UNDER ETHER.}

To the Editors of THE LANCET.

SIRs,-If Dr. Dudley W. Buxton refers to p. 467 , No. 8 , vol v., of the Occidental Medical Times, being the number for this month, he will find an account of the death of a healthy woman, forty one years of age, under etherisation. As the case is of some general interest, I send you a summary of it. The patient was admitted to hospital on June lst, 1891, for the removal of an intra-uterine fibroid. She had had similar tumours removed in the autumn of 1889 and the spring of 1890 , both operations having been performed under ether, "recovery being prompt" On admission the patient was very anæmic, but "the heart, lungs, and kidneys were in good condition. Fifteen minutes before the operation she was given one teaspoonful of aromatic spirit of ammonia and one tablespoonful of whisky, and when placed on the table she was in good condition." Twenty-five minutes after anæsthetisation "it was noticed that the heart was acting feebly. ...... Not more than five minutes elapsed from the first sign of heart failure until death supervened. Including the operator there were six physicians present, and it does not appear that anything further in the way of precaution or of prompt treatuent when signs of collapse were manifest could have been accomplished." The above is not only death during etherisation in a healthy person, but it is also death from heart failure, and in a patient who had no ether idiosyncrasy, for she twice previously inhaled the drug with impunity.

$$
\text { I am, Sirs, yours truly, }
$$

$$
\text { Dublin, Aug. 19th, } 1891 . \quad \text { GEORGE FOY, F.R.C.S.I. }
$$

THE TITLE OF “DR."

To the Editors of THE LANCET.

SiRs,- Though rather late in the day, now that the new degree-giving University is decided on, may I ask the following question? Would not the total abolition of the M.D. and prefix Doctor be a simple means of settling the "burning question"? The public would not mind, and the profession ought to rejoice should such a thing occur. The public do not care what a medical practitioner's qualifica. tions are if they think him a good doctor ; for a knowledge of his qualifications give them no help in solving the question as to whether be is a good doctor. The multiplicity of qualifications has quite mystified the public. The profession might be glad to relegate to limbo a little which serves to single its members ont from the rest of the world, and prevents them "dropping shop" as much as they might. Other men do not seem to require any special designation to indicate their occupation, and prevent them and their friends forgetting their vocation after work is done. Why should doctors? Have not doctors from the days of goldheaded canes down to now been a little too fond of airing their professionalism out of work hours? Is it an advantage to be announced by the servant on entering a room full of strangers as Dr. So-and-so, when the announcement is quite likely to be followed as one of the first remarks by, "Is there much sickness now, doctor?" Does the title Ur. Soand-so improve our social standing? Probably not. Has it not a narrowing influence on our ideas to be always talked to by people who, on account of the title Dr., must know our occupation, and probably frame their conversation accordingly? I believe that I am only one of many medical practitioners who think that if we did not differentiate ourselves so much, and were content to be like other educated members of the community in title, manners, and personal appearance, it would be better for ourselves both in public and private life.-I am, Sire, yours truly,

Godalming, Aug. 27th, 1891.

C. J. Gibson, M.B. 